NBER WORKING PAPER SERIES

\title{
EVIDENCE OF A SHIFT IN THE SHORT-RUN PRICE ELASTICITY OF GASOLINE DEMAND
}

Jonathan E. Hughes

Christopher R. Knittel

Daniel Sperling

Working Paper 12530

http://www.nber.org/papers/w12530

NATIONAL BUREAU OF ECONOMIC RESEARCH

1050 Massachusetts Avenue

Cambridge, MA 02138

September 2006

We thank Severin Borenstein for helpful comments. Hughes and Sperling thank the Hydrogen Pathways Program and the UC Davis Institute of Transportation Studies for supporting this research. Knittel thanks financial support from the University of California Energy Institute. The views expressed herein are those of the author(s) and do not necessarily reflect the views of the National Bureau of Economic Research.

(C) 2006 by Jonathan E. Hughes, Christopher R. Knittel, and Daniel Sperling. All rights reserved. Short sections of text, not to exceed two paragraphs, may be quoted without explicit permission provided that full credit, including $(\mathcal{O}$ notice, is given to the source. 
Evidence of a Shift in the Short-Run Price Elasticity of Gasoline Demand

Jonathan E. Hughes, Christopher R. Knittel, and Daniel Sperling

NBER Working Paper No. 12530

September 2006

JEL No. D12,L91,Q31,Q41,R40,R41

\begin{abstract}
Understanding the sensitivity of gasoline demand to changes in prices and income has important implications for policies related to climate change, optimal taxation and national security, to name only a few. While the short-run price and income elasticities of gasoline demand in the United States have been studied extensively, the vast majority of these studies focus on consumer behavior in the 1970s and 1980s. There are a number of reasons to believe that current demand elasticities differ from these previous periods, as transportation analysts have hypothesized that behavioral and structural factors over the past several decades have changed the responsiveness of U.S. consumers to changes in gasoline prices. In this paper, we compare the price and income elasticities of gasoline demand in two periods of similarly high prices from 1975 to 1980 and 2001 to 2006. The short-run price elasticities differ considerably: and range from -0.034 to -0.077 during 2001 to 2006 , versus -0.21 to -0.34 for 1975 to 1980 . The estimated short-run income elasticities range from 0.21 to 0.75 and when estimated with the same models are not significantly different between the two periods.
\end{abstract}

Jonathan E. Hughes

One Shields Ave

Davis, CA 95616

jehughes@ucdavis.edu

Christopher R. Knittel

University of California at Davis

Department of Economics

One Shields Ave

Davis, CA 95616

and NBER

crknittel@ucdavis.edu
Daniel Sperling

One Shields Ave

Davis, CA 95616

dsperling@ucdavis.edu 


\section{INTRODUCTION}

The short-run price and income elasticities of gasoline demand have been studied extensively in the literature. Dahl and Sterner (1991) and more recently, Espey (1998) provide thorough reviews based on hundreds of gasoline demand studies. However, past research has been primarily focused on the 1970s and early 1980s. Since that time, a number of structural and behavioral changes have occurred in the U.S. gasoline market. Transportation analysts have hypothesized that factors such as changing land-use patterns, implementation of the Corporate Average Fuel Economy program (CAFE), growth of multiple income households and per capita disposable income as well as a decrease in the availability of non-auto modes such as transit, have changed the responsiveness of U.S. consumers to changes in gasoline price. For example, a recent analysis of household data suggests that suburban households drive 31 to 35 percent more than their urban counterparts, Kahn (2000). In another study, Polzin and Chu (2005) find that the share of transit passenger miles traveled relative to other modes has steadily decreased over the past thirty years suggesting that U.S. consumers may be more dependent on automobiles than in previous decades.

Given recent interest in decreasing U.S. gasoline consumption and transportation related greenhouse gas emissions, there is a renewed interest in price-based policies such as gasoline or carbon taxes. In this context, it is especially important to consider whether gasoline demand elasticities have changed. This paper focuses on the short-run price and income elasticities of gasoline demand. Historically, estimates of gasoline demand elasticities have proven to be fairly robust. In their survey, Dahl and Sterner (1991) determine an average short-run price elasticity of gasoline demand of -0.26 and an average short-run income elasticity of gasoline demand of 0.48. Based on over 300 prior estimates for the U.S. and other developed countries, Espey (1998) finds a median short-run price elasticity of -0.23 and a median short-run income elasticity 
of 0.39. However, the studies surveyed in each paper are limited to the gasoline market of several decades past. ${ }^{1}$

Several authors have investigated U.S. demand for gasoline in more recent years. Puller and Greening (1999) and Nicol (2003) study the household demand for gasoline using data from the U.S. Consumer Expenditure Survey. Schmalensee and Stoker (1999) investigate the role of household characteristics on gasoline demand using data from the Residential Transportation Energy Consumption Survey. Kayser (2000) conducts a similar study using data from the Panel Study of Income Dynamics and includes adjustments in household vehicle stock. However, none of these studies allow for a direct comparison of short-run price and income elasticities between earlier time periods and today.

In this paper we estimate and compare the price and income elasticities of gasoline demand in two periods, from November 1975 through November 1980 and from March 2001 through March 2006. The periods chosen reflect a quasi-experimental design to control for the magnitude and rate of increase of real prices during two periods of high gasoline prices. Because elasticity estimates vary according to data type and empirical model specification (Espey, 1998), we use a consistent set of data and models between the two periods. Average U.S. per capita gasoline consumption and personal disposable income data are used in addition to average U.S. retail prices. Elasticities are estimated using several simple econometric models similar in form to those used in previous studies of gasoline demand. Our estimates of the shortrun price elasticity of gasoline demand for the period from 1975 to 1980 range between -0.21 and -0.34 and are consistent with previous results from the literature. For the period from 2001 to 2006 our estimates of price elasticity range from -0.034 to -0.077 . The estimated short-run income elasticities range from 0.21 to 0.75 and when estimated with the same models are not significantly different between the two periods.

\footnotetext{
${ }^{1}$ The most recent study surveyed by Espey (1998) contains data from 1993.
} 
We conclude that the short-run price elasticity of gasoline demand is significantly more inelastic today than in previous decades. In the short-run, consumers appear significantly less responsive to gasoline price increases. We discuss a number of possible explanations for this result in terms of shifts in land-use and social or vehicle characteristics during the past several decades. Finally, we explore policy implications in light of future efforts to reduce U.S. gasoline consumption.

\section{BASIC MODEL AND DATA}

\subsection{Basic Model}

The econometric models used in this paper reflect previous studies of gasoline demand. Our base model specifies the log of gasoline consumption as a function of the log of price and income. Specifically, we estimate: ${ }^{2}$

$$
\ln G_{j t}=\beta_{o}+\beta_{1} \ln P_{j t}+\beta_{2} \ln Y_{j t}+\varepsilon_{j}+\varepsilon_{j t}
$$

where $G_{j t}$ is per capita gasoline consumption in gallons in month $j$ and year $t, P_{j t}$ is the real retail price of gasoline in month $j$ and year $t, Y_{j t}$ is real per capita disposable income in month $j$ and year $t, \varepsilon_{j}$ represents unobserved demand factors that vary at the month level and $\varepsilon_{j t}$ is a mean zero error term. Both $Y_{j t}$ and $P_{j t}$ are in constant 2000 dollars. We model the $\varepsilon_{j}$ 's as fixed month effects to capture the seasonality present in gasoline consumption.

Although some, including Hsing (1990), have rejected the double-log functional form, it is a common specification used in a large number of previous studies. It is adopted here as it provides a good fit to the data and allows for direct comparison with previous results from the literature. Regardless, we also present results for linear and semi-log specifications.

\footnotetext{
${ }^{2}$ For example see Dahl (1979) or Houthakker et. al. (1974).
} 


\subsection{Basic Model Data}

The data used in the analysis are U.S. aggregate monthly data reported by several U.S. government agencies for the period from January 1974 to March 2006. Aggregate data are used due to the lack of data at the regional or state level for all independent variables in the appropriate time period. Gasoline consumption is approximated as monthly "product supplied" reported by the U.S. Energy Information Administration (2006), which is calculated as domestic production plus imports, less exports and changes to stocks. Real gasoline prices are U.S. city average prices for unleaded regular fuel from the U.S. Bureau of Labor Statistics (2006), CPIAverage Price Data. ${ }^{3}$ Personal disposable income is from the U.S. Bureau of Economic Analysis (2006), National Economic Accounts. Prices and income are converted to constant 2000 dollars using GDP implicit price deflators from the Bureau of Economic Analysis (2006).

Figure 1 below shows per capita monthly gasoline consumption and real prices for the period from January 1974 to March 2006. In order to compare gasoline demand elasticities today with those of previous decades, two 5-year periods were selected for analysis, November 1975 through November 1980 and March 2001 through March 2006. Figure 2 below shows the monthly real retail price of gasoline for each period. The peak price in each case is approximately \$2.50 per gallon with a slightly higher price in the more recent period. The peak price in both cases represents an increase of approximately $\$ 1.00$ relative to the price at the beginning of the period. In addition, the average monthly per capita gasoline consumption is roughly equivalent between the two periods with mean $40.4 \mathrm{gal} / \mathrm{month}$ and $39.2 \mathrm{gal} / \mathrm{month}$ and standard deviation of $2.8 \mathrm{gal} / \mathrm{month}$ and $1.7 \mathrm{gal} / \mathrm{month}$ for the 1975-1980 and 2001-2006 periods, respectively.

The choice of these two periods represents a quasi-experimental design where we attempt to control for the magnitude of real price, consumption and the duration of price changes by selecting periods with similar real price and consumption characteristics. This enables a direct

\footnotetext{
${ }^{3}$ Price data on unleaded regular were unavailable prior to 1976 and as a result, 1975 data are for leaded regular.
} 
comparison of the elasticity estimates for each period. Given the nature of real economic data, it is impossible to construct a perfect controlled experiment. The potential impact on the estimated elasticities is difficult to predict. Because the peak price is higher and the price spikes are sharper in the 2001 to 2006 data, one might expect the price elasticity to be more elastic during this period. Alternatively, the period from 1975 to 1980 is characterized by a longer period of elevated prices which might tend to increase elasticity by allowing consumers more time to adjust to elevated prices. All in all, the real price data is remarkably similar between the two periods providing for a suitable comparison of elasticity estimates.

\subsection{Basic Model Results}

The empirical models described in Section 2.1 were estimated for each period using ordinary least squares (OLS). In all estimates, we report Newey-West standard errors to control for heteroskedasticity and autocorrelation. ${ }^{4}$ Table 1 provides a summary of the estimated parameters for the basic double-log model in the periods from 1975 to 1980 and from 2001 to 2006. The model provides a good fit to the data with adjusted $R$-squareds of 0.85 and 0.94 in the early and more recent periods, respectively. The monthly fixed effects illustrate the strong seasonality effects present in the demand for gasoline. Signs are consistent with the expectation that gasoline demand is high during the summer months and lower during the winter. The magnitudes of seasonal effects are similar between the two periods although the winter effect is somewhat smaller today than in the period from 1975 to 1980.

In Table 2, we present the results from two alternative functional forms alongside the double-log functional form. The monthly dummy variables have been excluded to simplify presentation of the results. The coefficients on price and income are significant $(p<0.01)$ for the basic model irrespective of functional form. Table 3 summarizes the average elasticities for the three models; estimates of the price elasticity of gasoline demand range from -0.31 to -0.34

\footnotetext{
${ }^{4}$ Using the GNU Regression, Econometric and Time-Series Library (GRETL) robust regression routine and a 12month lag order.
} 
in the period from 1975 to 1980 and from -0.041 to -0.043 in the period from 2001 to 2006 . Assuming that the samples from each period are independent, we perform a Student's t-test on the elasticity estimates for each model and in all cases reject the null hypothesis that the price elasticities are the same in the two periods. ${ }^{5}$ The income elasticity of gasoline demand ranges from 0.47 to 0.49 for the period from 1975 to 1980 and from 0.53 to 0.54 in the period from 2001 to 2006. In this case, we fail to reject the null hypothesis that the income elasticities are different in the two periods.

\section{ALTERNATIVE SPECIFICATIONS AND RESULTS}

In order to test the robustness of the price and income elasticity estimates produced by the basic model, we employ a number of alternate model specifications in an attempt to decrease the early period elasticity or increase the recent period elasticity. Sections 3.1, 3.2, 3.3 and 3.4 outline alternate model specifications.

\subsection{Recession and Estimation with Macroeconomic Variables}

In this section we investigate the possibility that the early period elasticity estimates are biased upward because of omitted variables. The period of high gasoline prices from 1975 to 1980 coincided with an economic recession in the United States. To the extent that factors such as high unemployment and inflation contributed to changes in gasoline consumption during this period, it is important to account for historical macroeconomic conditions in our elasticity estimates. Using the basic double-log model we estimate price and income elasticities using as explanatory variables unemployment rate $(U E)$, interest rate ${ }^{6}(B R)$ and inflation rate $(I N R)$ in addition to real price, income and fixed month effects. If the economic recession contributed to

${ }^{5} t_{c}=\frac{E_{p}^{1975-1980}-E_{p}^{2001-2006}}{\sqrt{\left(s_{p}^{1975-1980}\right)^{2}+\left(s_{p}^{2001-2006}\right)^{2}}}$.

${ }^{6}$ Interest rates as indicated by interest rates for 1-year and 10-year U.S. Treasury Bills. 
a decrease in gasoline consumption during the period from 1975 to 1980, failure to account for this effect would artificially inflate the estimated price elasticity.

Results for the basic double-log model incorporating macroeconomic variables are presented in Table 4. Results using 1-year and 10-year bond interest rates are shown. The macroeconomic variables are jointly significant with F-statistics of 12.48 and 12.66 for the 1year and 10-year interest rate models, respectively. The coefficients on unemployment rate and inflation rate are independently significant in each model $(p<0.05)$. As expected, accounting for the effect of the recession during the period from 1975 to 1980 produces more inelastic price elasticity estimates of -0.22 and -0.21 for the 1 -year and 10 -year interest rate models, respectively. ${ }^{7}$ The estimated income elasticities are also more inelastic at 0.33 and 0.38 .

\subsection{Simultaneous Equations Models}

A well known problem in estimating demand equations occurs when price and quantity are jointly determined through shifts in both supply and demand resulting in biased and inconsistent parameter estimates. This problem is especially important when attempting to compare elasticity estimates between two periods. One potential explanation for the estimated elasticity differences is that the high prices of 1975 to 1980 were largely supply driven, while the high prices of 2001 to 2006 were demand driven; the endogeneity of prices and quantities would result in more elastic elasticity estimates in the 1970s and 1980s and less elastic estimates in the 2000s.

To address this concern, we instrument for price in the late period. An ideal instrumental variable for determining gasoline demand is one that is highly correlated with the price of gasoline (the endogenous variable) but not with unobserved shocks to gasoline demand. With respect to selection of instrumental variables, Ramsey, et al. (1975) and Dahl (1979) have used the relative prices of refinery products such as kerosene and residual fuel oil as instrumental variables. The problem with this approach is that the relative prices of other refinery outputs are

\footnotetext{
${ }^{7}$ Using the same models with macroeconomic data results in an estimated price elasticity of approximately -0.03 for the period from 2001 to 2006.
} 
likely to be correlated with gasoline demand shocks. Since gasoline demand and oil price are correlated, gasoline demand is likely correlated with the prices of other refinery outputs via the price of oil.

As it turns out, identifying appropriate instrumental variables for gasoline demand is difficult. In this paper we experiment with two types of instrumental variables: crude oil quality and crude oil production disruptions. Here we define crude oil input quality by sulfur content $\left(S_{j t}\right)$ and American Petroleum Institute specific gravity $\left(A P I_{j t}\right)$. Since environmental regulations require the removal of sulfur from gasoline, higher sulfur content crude oil presumably increases the cost of manufacturing gasoline due to higher sulfur removal costs. Heavier crude oils are characterized by lower API specific gravity and require more “cracking” to produce gasoline than do lighter crude oil inputs. Therefore, one would expect gasoline price to be positively correlated with sulfur content and negatively correlated with API gravity. Crude oil production disruptions are represented for three countries, Venezuela $\left(V Z_{j t}\right)$, Iraq $\left(I Q_{j t}\right)$ and the United States $\left(U S_{j t}\right)$. These three countries were selected because each has had its production of crude oil affected by external shocks that are unlikely to be related to gasoline demand shocks. In Venezuela, a strike by oil workers beginning in December 2002 cut production to near zero and has significantly affected output for several years. In Iraq, an international embargo and, more recently, war have caused major disruptions to oil operations. In the United States, production has been in steady decline since the 1970s due to declining resources. In 2005, hurricanes Katrina and Rita resulted in the temporary loss of several hundred thousand barrels of production in the Gulf of Mexico.

For each country, crude oil production disruptions are defined by the difference between actual production and a production forecast, ${ }^{8}$ for example $V Z_{j t}=$ production - forecast ${ }^{9}$ The start of each disruption is defined by a specific event leading to a loss in production. In

\footnotetext{
${ }^{8}$ For forecasted oil production in each country, we employ a simple double-log model using only a time trend and fixed month effects as explanatory variables.

${ }^{9}$ In unreported results, we instead used a set of indicator variables representing the supply shocks. The results were qualitatively similar.
} 
Venezuela, the disruption start corresponds with the oil worker strike beginning in December of 2002 as reported by Banerjee (2002). In Iraq we use the beginning of the second Gulf War in March of 2003 as reported by Tyler (2003). Finally, in the U.S., hurricane Katrina marks the beginning of the disruption reported by Mouawad and Bajaj (2005) in September 2005. The end of each disruption is defined as the month in which actual production reaches the forecasted production level. In the U.S., the forecast and production do not converge, but because production follows a highly seasonal pattern, the disruption end date is defined by the winter production peak marking the return to "normal” operations. Based on these definitions, the disruption periods are, December 2002 through March 2003 (VZ), March 2003 through November 2003 (IQ) and September 2005 through January 2006 (USA).

Using these instruments, we estimate Equation (1) via two-stage least squares (2SLS). Unfortunately, data on several instrumental variables are not available for the entire study period. This prevents analysis of gasoline demand in the period from 1975 to 1980 using the instrumental variable approach. However, our goal is to determine if the elasticity differences we estimate are due to a bias in the later period estimates.

To gauge the strength of the instruments, Table 5 summarizes the coefficient estimates when we regress the log of real gasoline price on each of the sets of instruments. Crude oil quality does not prove to be an appropriate instrumental variable, as the coefficients on sulfur content $(S)$ and specific gravity $(A P I)$ are not significant. U.S. crude oil production disruption (USA) is found to be significant $(p<0.01)$, however the coefficients on production disruptions in Venezuela and Iraq are not significant ( $p=0.13$ and $p=0.22$, respectively). Given these results, we also report the results when using only disruptions in U.S. production.

Table 6 compares the 2SLS estimates. Crude oil quality does not produce a significant result, as foreshadowed by the first stage results. Crude oil production disruptions appear to be the best set of instruments. ${ }^{10}$ In both the three-country and USA-only cases the price and income

\footnotetext{
${ }^{10}$ We attempted a 2SLS regression using U.S. production disruptions together with crude oil quality as instruments, however the coefficients on the crude oil quality variables were not significant in the first stage regression.
} 
coefficients are significant $(p<0.01)$. The estimated price elasticities are -0.060 and -0.077 for the three-country and USA-only cases, respectively. In the case of the USA-only model, the price elasticity estimate for the period from 2001 to 2006 is more elastic and significantly different from the basic model estimate for the same period. However, the price elasticity is still small relative to the price elasticity estimates for the period from 1975 to 1980 . While we cannot rule out the effects of simultaneity, the instrumental variable results are encouraging and suggest that these effects may be small relative to other factors affecting price elasticity.

\subsection{Price Income Interaction Parameter Model}

In order to study the interaction between the price elasticity of demand and income, we utilize a simple interaction model of the form of Equation 2 below. The interaction term, $\ln P_{j t} \ln Y_{j t}$ captures the extent to which the responsiveness of consumers to price changes increases or decreases as income changes. ${ }^{11}$ In this specification, the price elasticity of gasoline demand is equal to $E_{p}=\beta_{1}+\beta_{3} \ln Y_{j t}$. Since the price elasticity is less than zero, a positive coefficient $\beta_{3}$ on the interaction term indicates a decrease in the price response as income rises.

$$
\ln G_{j t}=\beta_{o}+\beta_{1} \ln P_{j t}+\beta_{2} \ln Y_{j t}+\beta_{3} \ln P_{j t} \ln Y_{j t}+\varepsilon_{j}+\varepsilon_{j t}
$$

Results from OLS estimation of the price-income interaction model and partial adjustment models are presented in Table 7 below. In the case of the price-income interaction model, the coefficients on price, income and the interaction term are significant for the period from 1975 to $1980(p<0.05)$ and for the period from 2001 to $2006(p<0.01)$.

\subsection{Partial Adjustment Models}

Another common approach to modeling gasoline demand is through the use of a partial adjustment model. $^{12}$ For example, see Houthakker, et al. (1974). The partial adjustment (PA)

\footnotetext{
${ }^{11}$ We also investigated the possibility of quadratic relation between price elasticity and income using an interaction term of the form $\ln P_{j t}\left(\ln Y_{j t}\right)^{2}$. However, colinearity between $\ln Y_{j t}$ and $\left(\ln Y_{j t}\right)^{2}$ made this analysis impossible.

${ }^{12}$ Recently, a number of authors have used alternate dynamic models of gasoline demand based on cointegration techniques. For example, see Alves and Bueno (2003), Bentzen (1994), Eltony and Almutairi (1995), and Ramanathan (1999). We also investigated this approach. Tests for cointegration provided mixed results. In augmented Dickey-Fuller tests we failed to reject the unit root hypothesis for the residuals of the cointegrating
} 
model is a dynamic model that includes a lagged dependent variable. The rationale is that frictions in the market prevent reaching the appropriate equilibrium level and as a result, only a fraction of the desired change in consumption between periods is realized. In this paper, we estimate models with both 1-month $(t-1)$ and 12-month $(t-12)$ lags with and without fixed month effects. Here we use $\ln G_{j t}$ * in Equation 3 to represent the log of the equilibrium level of gasoline consumption. The realized consumption in month $j$ and year $t, \ln G_{j t}$ is given by consumption in the previous period, $\ln G_{j t-1}$ plus a fraction $\lambda$ (adjustment coefficient) of the difference between $\ln G_{j t}$ * and $\ln G_{j t-1}$ as shown in Equation 4 below.

$$
\begin{aligned}
& \ln G_{j t}^{*}=\beta_{o}+\beta_{1} \ln P_{j t}+\beta_{2} \ln Y_{j t} \\
& \ln G_{j t}=G_{j t-1}+\lambda\left(G_{j t} *-G_{j t-1}\right)+\varepsilon_{j t}, 0<\lambda<1
\end{aligned}
$$

Substituting for $\ln G_{j t}$ * in Equation 4 yields Equation 5 below which is estimated by OLS. The short-run price and income elasticities are given by the coefficients $\xi_{2}$ and $\xi_{3}$, respectively. The fully adjusted coefficients on the price and income terms, $\xi_{2,3} / \lambda=\xi_{2,3} /\left(1-\xi_{1}\right)$ are generally interpreted as long-run elasticities. However, the interpretation is not as clear when monthly data are used. If the speed of adjustment $(1 / \lambda)$ is relatively short, on the order of several months, the fully adjusted elasticities may also be interpreted as short-run. In Section 3.5, both the short-run and fully adjusted coefficients are reported for comparison.

$$
\ln G_{j t}=\xi_{o}+\xi_{1} G_{j t-1}+\xi_{2} \ln P_{j t}+\xi_{3} \ln Y_{j t}+\varepsilon_{j t}
$$

The partial adjustment models provide mixed results. In the partial adjustment models without monthly dummy variables, the $\ln G_{t-1}$ lag model does not fit the empirical data. For the 12-month lag, the coefficient on income is not significant in either period. Therefore, we exclude the results of these models from the elasticity comparison. Incorporating fixed month

regressions, I(12). However, the Durbin-Watson statistics for the cointegrating regressions suggested the presence of cointegration, I(12). When we applied an error correction model similar to Alves and Bueno (2003) we obtained elasticity estimates consistent with results from our other models. 
effects improves the fit somewhat. For the period from 2001 to 2006, the coefficients on price, income and the lagged dependent variable are significant $(p<0.01)$ for both lag structures. For the period from 1975 to 1980, however, the coefficients on the lagged dependent variable and on income are not significant in the 1-month and 12-month lag models, respectively. Therefore, we also exclude the results for this period from the comparison of gasoline elasticities. With respect to the 2001 to 2006 results, the speed of adjustment is approximately 1.5 and 9.4 months for the 1-month and 12-month models, respectively. This suggests that the fully adjusted elasticity estimates may be interpreted as short-run estimates and are included below for comparison.

\subsection{Summary of Alternative Specifications Results}

The estimated price and income elasticities of gasoline demand for alternate model specifications are summarized in Table 8 below. Based on the price income interaction, simultaneous equations and recession data models, the estimated price elasticity of gasoline demand is between -0.21 and -0.22 in the period from 1975 to 1980 and between -0.034 and -0.077 in the period from 2001 to 2006. While the partial adjustment models do not provide a basis for comparison between the two periods, the estimated price and income elasticities in the period from 2001 to 2006 are consistent with other model specifications. A student's t-test of the simultaneous equations and recession data model results shows that the estimated price elasticities in the two periods are significantly different $(t=3.15)$ even in the most conservative case.

\section{DISCUSSION}

The results presented here strongly support the existence of a structural change in the demand for gasoline. Estimates of the short-run price elasticity of gasoline demand for the period from 1975 to 1980 range from -0.21 and -0.34 and are consistent with estimates from the literature that use comparable data. However, estimates of the price elasticity for the more recent period are significantly more inelastic ranging from -0.034 to -0.077 . This result has important policy implications. 
The short-run price elasticity is a measure of the change in driving behavior as a result of a change in the price of gasoline. A driver's response to higher prices is largely composed of a reduction in the amount of driving (vehicle miles traveled) and an increase in the fuel efficiency of driving. The fuel efficiency of driving can be increased through for example, improved vehicle maintenance or changes in driving behavior such as slower acceleration or reduced vehicle speed. In addition, shifts in household vehicle stock utilization may contribute to shortrun elasticity. The short-run elasticity may also include more permanent changes in the vehicle stock (e.g., the purchase of more fuel efficient vehicles), though vehicle purchase decisions are typically regarded as more long-run in nature. The results presented here suggest that on average, U.S. drivers appear less responsive in adjusting to gasoline price increases than in previous decades.

It may be the case today that U.S. consumers are more dependent on automobiles for daily transportation than during the 1970's and 1980's and as a result, are less able to reduce vehicle miles traveled in response to higher prices. One hypothesis is that an increase in suburban development has led to larger distances between travel destinations. This could mean that drivers have less ability to respond to price changes because greater distances decrease the viability of non-motorized modes such as walking or biking. In addition, when development patterns increase the distance between home and non-discretionary destinations such as the workplace, a greater share of the total vehicle miles traveled are fixed. An increase in multiple income households would further decrease flexibility if a greater share of the population requires a daily work commute. Finally, these effects are compounded if the availability of public transit is less than in earlier decades.

Another hypothesis is that as incomes have grown, the budget share represented by gasoline consumption has decreased making consumers less sensitive to price increases. The price income interaction model presented here provides insight into this hypothesis. If increasing income results in a decrease in the consumer response to gasoline price changes, one would expect the coefficient on the interaction term of the model to have a positive sign. 
However, in both periods we find that the coefficient on the interaction term is negative suggesting that on average, gasoline consumption is more sensitive to price changes as income rises. This somewhat counterintuitive result is supported by the household gasoline demand analysis conducted by Kayser (2000) who also finds a negative coefficient on the price income interaction term. The hypothesis proposed by Kayser is that as incomes rise, a greater proportion of automobile trips are discretionary. Alternatively, at lower income levels, the amount of travel has already been reduced to the minimum leaving little room for adjustment to higher prices. Another possible explanation is that the number of vehicles per household increases with income. When the number of household vehicles exceeds the number of drivers, there is the possibility for drivers to shift to more fuel efficient vehicles within the household stock as gasoline prices rise. Whatever the explanation, the overall decrease in price elasticity despite growth in incomes suggests that these effects are relatively minor compared to other factors affecting gasoline demand.

Finally, the overall improvement in U.S. fleet average fuel economy since the late 1970’s and early 1980's may have also contributed to a decrease in the responsiveness of consumers to gasoline price increases. Largely a result of the U.S. Corporate Average Fuel Economy (CAFE) and market penetration of fuel efficient foreign vehicles during the period, the U.S. fleet average fuel economy improved from approximately 15 miles per gallon in 1980 to approximately 20 miles per gallon in 2000 according to National Research Council (2002). Because the vehicle fleet has become more fuel efficient, a decrease in miles traveled today has a smaller impact on gasoline consumption. That is to say if for example discretionary travel is reduced, the resulting reduction in gasoline consumption today is less than in 1980 because today's vehicles consume less fuel per mile driven.

To some degree, the short-run price elasticity during the 1970’s and 1980's may also reflect the large difference in fuel economy between old and new vehicles that existed during the transition to higher fuel economy standards. As more fuel efficient vehicles came to market, it was possible for consumers to realize a large improvement in fuel economy by trading in older 
vehicles for newer models. Today however, there is little difference in fuel economy between old and new vehicles. This is largely a result of CAFE standards that have not been significantly increased since the 1980's. As a result, today's new vehicle market forces consumer to choose between smaller vehicle classes or more expensive hybrid models when considering options for improving vehicle fuel economy. The inelastic price elasticities observed in the more recent period of this study may be a continuation of a trend identified by Espey (1998) who observed that short-run price elasticities appeared to decrease in magnitude over time. Espey argues that as prices rose during the 1970's and people initially changed driving habits and bought more fuel efficient vehicles there were fewer short-run options to respond to increasing prices in the future.

Whatever the cause, the results presented here suggest that today's consumers have not significantly altered their driving behavior in response to higher gasoline prices. It is important to note that these results measure consumers' reactions to short run changes in gasoline prices. However, it is the long-run response that is the most important in determining which polices are most appropriate for reducing gasoline consumption. As it turns out, it is relatively difficult to measure long-run gasoline elasticities in practice due to factors such as the cyclical nature of gasoline prices. In this paper, we are also limited to currently available data and the relatively short history of high gasoline prices during the past several years.

Analysis of the short-run price elasticity does however provide some insight into long-run behavior. The long-run response to gasoline price increases is the sum of short-run changes (miles driven) and long-run changes (fuel economy of the vehicle fleet). The short-run results suggest that consumers today are less responsive in adjusting miles driven to increases in gasoline price. This component seems unlikely to change significantly for long-run behavior. This is because factors that may contribute to inelastic short-run price elasticities such as land use, employment patterns and transit infrastructure typically evolve on timescales greater than those considered in long-run decisions.

In terms of vehicle fuel economy, consumers may respond to higher gasoline prices in the long-run by purchasing more fuel efficient vehicles. However, if consumers in the period from 
2001 to 2006 were purchasing more fuel efficient vehicles in response to higher gasoline prices, one would expect to see at least a portion of this effect in the short-run elasticity. While our results do not preclude a significant shift to more fuel efficient vehicles in the long-run response, the highly inelastic values that we observe suggest that the vehicle fuel economy component is small. If the long-run price elasticity is in fact more inelastic than in previous decades, smaller reductions in gasoline consumption will occur for any given gasoline tax level. As a result, a tax would need to be significantly larger today in order to achieve an equivalent reduction in gasoline consumption. In the U.S., gasoline taxes have been politically difficult to implement. Higher required tax levels pose an addition hurdle. This may make tax policies impossible to implement in practice. In this case, alternate measures such as increases in the CAFE standard may be required to achieve desired reductions in gasoline consumption.

\section{SUMMARY AND CONCLUSIONS}

In this paper we estimate the average per capita demand for gasoline in the U.S. for the period from 1974 to 2006. We investigate two periods of similar gasoline price increases in order to compare the demand elasticities in the 1970's and 1980's with today. We find that the short-run price elasticity of U.S. gasoline demand is significantly more inelastic today than in previous decades. This result is robust and consistent across several empirical models and functional forms. The observed change provides evidence of a structural change in the U.S. market for transportation fuel and may reflect shifts in land-use, social or vehicle characteristics during the past several decades. These results suggest that technologies and policies for improving vehicle

fuel economy may be increasingly important in reducing U.S. gasoline consumption. 


\section{REFERENCES}

Alves, D. C. O. and Bueno, R. D. (2003). "Short-Run, Long-Run and Cross Elasticities of Gasoline Demand in Brazil." Energy Economics 25(2): 191-199.

Bentzen, J. (1994). "An Empirical-Analysis of Gasoline Demand in Denmark Using Cointegration Techniques." Energy Economics 16(2): 139-143.

Banerjee, N. (2002). "Venezuela Strife Pushes Crude Oil to \$30." The New York Times. Late Edition - Final. C 1. December 17, 2002.

Bureau of Economic Analysis, National Economic Accounts, Implicit Price Deflators for Gross Domestic Product. http://www.bea.gov/bea/dn/nipaweb/index.asp. Accessed May 19, 2006.

Bureau of Economic Analysis, National Economic Accounts, Personal Income and Its Disposition. U.S. Department of Commerce. http://www.bea.gov/bea/dn/nipaweb/index.asp. Accessed May 19, 2006.

Dahl, C. and Sterner, T. (1991). "Analyzing Gasoline Demand Elasticities: A Survey." Energy Economics 3(13): 203-210.

Dahl, C. A. (1979). "Consumer Adjustment to a Gasoline Tax." The Review of Economics and Statistics 61(3): 427-432.

Eltony, M. N. and Almutairi, N. H. (1995). "Demand for Gasoline in Kuwait - an EmpiricalAnalysis Using Cointegration Techniques." Energy Economics 17(3): 249-253.

Espey, M. (1998). "Gasoline Demand Revisited: An International Meta-Analysis of Elasticities." Energy Economics 20: 273-295.

Houthakker, H. S., Verleger, P. K. and Sheehan, D. P. (1974). "Dynamic Demand Analysis for Gasoline and Residential Electricity." American Journal of Agricultural Economics 56(2): 412-418.

Hsing, Y. (1990). "On the Variable Elasticity of the Demand for Gasoline." Energy Economics 12(2): 132-136.

Kahn, M. E. (2000). "The Environmental Impact of Suburbanization." Journal of Policy Analysis and Management 19(4): 569-586.

Kayser, H. A. (2000). "Gasoline Demand and Car Choice: Estimating Gasoline Demand Using Household Information." Energy Economics 22(3): 331-348.

Mouawad, J. and Bajaj, V. (2005). "Gulf Oil Operations Remain in Disarray." The New York Times. Late Edition - Final. C 1. September 2, 2005.

National Research Council, (2002). Effectiveness and Impact of Corporate Average Fuel Economy (CAFE) Standards. National Academy Press.

Nicol, C. J. (2003). "Elasticities of Demand for Gasoline in Canada and the United States." Energy Economics 25(2): 201-214.

Polzin, S. E. and Chu, X. (2005). "A Closer Look at Public Transportation Mode Share Trends." Journal of Transportation and Statistics 8(3): 41-53.

Puller, S. L. and Greening, L. A. (1999). "Household Adjustment to Gasoline Price Change: An Analysis Using 9 Years of Us Survey Data." Energy Economics 21(1): 37-52.

Ramanathan, R. (1999). "Short- and Long-Run Elasticities of Gasoline Demand in India: An Empirical Analysis Using Cointegration Techniques." Energy Economics 21(4): 321-330.

Ramsey, J., Rasche, R. and Allen, B. (1975). "An Analysis of the Private and Commercial Demand for Gasoline." The Review of Economics and Statistics 57(4): 502-507. 
Schmalensee, R. and Stoker, T. M. (1999). "Household Gasoline Demand in the United States." Econometrica 67(3): 645-662.

Tyler, P. E. (2003). "A Nation at War: The Attack; U.S. And British Troops Push into Iraq as Missiles Strike Baghdad Compound." The New York Times. Late Edition - Final. A 1. March 21, 2003.

U.S. Bureau of Labor Statistics, Bureau of Labor Statistics Data, Prices and Living Conditions. U.S. Department of Labor. http://www.bls.gov/data/home.htm. Accessed May 15, 2006.

U.S. Bureau of Labor Statistics, Labor Force Statistics from the Current Population Survey. U.S. Department of Labor. http://data.bls.gov/PDQ/outside.jsp?survey=ln. Accessed August 25, 2006.

U.S. Energy Information Administration, International Petroleum Monthly, World Crude Oil Production. U.S. Department of Energy. www.eia.doe.gov/emeu/ipsr/t11c.xls. Accessed July 26, 2006.

U.S. Energy Information Administration, Petroleum Navigator, Crude Oil Input Qualities. http://tonto.eia.doe.gov/dnav/pet/pet_pnp_crq_dcu_nus_m.htm. Accessed July 25, 2006.

U.S. Energy Information Administration, Petroleum Navigator, Supply and Disposition. U.S. Department of Energy.

http://tonto.eia.doe.gov/dnav/pet/pet_sum_snd_c_nus_epm0f_mbbl_m.htm. Accessed May 15, 2006.

U.S. Federal Reserve Board, Federal Reserve Statistical Release, Selected Interest Rates. U.S. Federal Reserve Board. http://www.federalreserve.gov/RELEASES/h15/data.htm. Accessed August 24, 2006. 


\section{TABLE TITLES}

TABLE 1 OLS Regression Results - Double-Log Basic Model

TABLE 2 OLS Regression Results - Basic Model

TABLE 3 Price and Income Elasticities - Basic Model

TABLE 4 OLS Regression Results - Macroeconomic Variables

TABLE 5 Instrumental Variables for Gasoline Demand

TABLE 6 2SLS Regression Results - Instrumental Variable Models

TABLE 7 OLS Regression Results - Alternate Specifications

TABLE 8 Price and Income Elasticities - Alternative Specifications 


\section{FIGURE CAPTIONS}

FIGURE 1 Monthly Per Capita Gasoline Consumption and Real Retail Gasoline Price for January 1974 to March 2006.

FIGURE 2 Real Retail Gasoline Price for Two Periods from November 1975 through November 1980 and March 2001 through March 2006. 
Table 1

Basic Model: Double Log

\begin{tabular}{|c|c|c|}
\hline & $1975-1980$ & $2001-2006$ \\
\hline$\beta_{\text {o }}$ & $\begin{array}{c}-0.615 \\
(0.929)\end{array}$ & $\begin{array}{c}-1.697^{\star \star \star} \\
(0.587)\end{array}$ \\
\hline $\ln (P)$ & $\begin{array}{c}-0.335^{\star \star \star} \\
(0.024)\end{array}$ & $\begin{array}{c}-0.042^{\star \star \star} \\
(0.009)\end{array}$ \\
\hline $\ln (Y)$ & $\begin{array}{c}0.467^{\star \star \star *} \\
(0.096)\end{array}$ & $\begin{array}{c}0.530 \text { *** } \\
(0.058)\end{array}$ \\
\hline Jan & $\begin{array}{c}-0.079 * \star \star \\
(0.010)\end{array}$ & $\begin{array}{c}-0.044^{\star \star \star} \\
(0.006)\end{array}$ \\
\hline Feb & $\begin{array}{c}-0.129 * \star \star \\
(0.019)\end{array}$ & $\begin{array}{c}-0.122^{\star \star \star} \\
(0.010)\end{array}$ \\
\hline Mar & $\begin{array}{c}-0.019 * * * \\
(0.006)\end{array}$ & $\begin{array}{c}-0.008 \\
(0.005)\end{array}$ \\
\hline Apr & $\begin{array}{c}-0.021 \\
(0.016)\end{array}$ & $\begin{array}{c}-0.024^{\star \star \star} \\
-0.005\end{array}$ \\
\hline May & $\begin{array}{l}0.013 \\
(0.011)\end{array}$ & $\begin{array}{c}0.026^{\star \star *} \\
(0.004)\end{array}$ \\
\hline Jun & $\begin{array}{l}0.020 \\
(0.010)\end{array}$ & $\begin{array}{l}0.000 \\
(0.004)\end{array}$ \\
\hline Jul & $\begin{array}{c}0.031^{\star * \star} \\
(0.010)\end{array}$ & $\begin{array}{c}0.040 * \star * \\
(0.005)\end{array}$ \\
\hline Aug & $\begin{array}{c}0.042^{\star \star \star} \\
(0.010)\end{array}$ & $\begin{array}{c}0.046^{\star \star \star} \\
(0.004)\end{array}$ \\
\hline Sep & $\begin{array}{c}-0.028^{\star \star \star} \\
(0.006)\end{array}$ & $\begin{array}{c}-0.039 * \star * \\
(0.005)\end{array}$ \\
\hline Oct & $\begin{array}{l}0.002 \\
(0.010)\end{array}$ & $\begin{array}{l}0.008 \\
(0.005)\end{array}$ \\
\hline Nov & $\begin{array}{c}-0.058^{\star \star \star} \\
(0.012)\end{array}$ & $\begin{array}{c}-0.032^{* \star *} \\
(0.004)\end{array}$ \\
\hline$\varepsilon_{j}{ }^{\prime} s$ & $y$ & $\mathrm{y}$ \\
\hline $\bar{R}^{2}$ & 0.85 & 0.94 \\
\hline \multirow[t]{2}{*}{$\hat{\sigma}$} & 0.027 & 0.011 \\
\hline & $(p<0.01)$ & \\
\hline
\end{tabular}


Table 2

Basic Model

\begin{tabular}{|c|c|c|c|c|c|c|}
\hline & \multicolumn{2}{|c|}{ Basic Model: Linear } & \multicolumn{2}{|c|}{ Basic Model: Semi-Log } & \multicolumn{2}{|c|}{ Basic Model: Double-Log } \\
\hline & $1975-1980$ & $2001-2006$ & $1975-1980$ & $2001-2006$ & $1975-1980$ & $2001-2006$ \\
\hline$\beta_{0}$ & $\begin{array}{c}34.006 \\
(3.868)\end{array}$ & $\begin{array}{c}20.254 \\
(2.460)\end{array}$ & $\begin{array}{l}3.554 \\
(0.098)\end{array}$ & $\begin{array}{l}3.183 \\
(0.064)\end{array}$ & $\begin{array}{l}-0.615 \\
(0.929)\end{array}$ & $\begin{array}{l}-1.697 \\
(0.587)\end{array}$ \\
\hline$P$ & $\begin{array}{l}-7.252 \\
(0.554)\end{array}$ & $\begin{array}{l}-1.018 \\
(0.174)\end{array}$ & $\begin{array}{l}-0.180 \\
(0.013)\end{array}$ & $\begin{array}{l}-0.026 \\
(0.005)\end{array}$ & & \\
\hline$Y$ & $\begin{array}{l}1.254 \mathrm{E}-03 \\
(2.633 \mathrm{E}-04)\end{array}$ & $\begin{array}{l}\text { 7.943E-04 } \\
(9.862 \mathrm{E}-05)\end{array}$ & $\begin{array}{c}3.018 \mathrm{E}-05 \\
(6.536 \mathrm{E}-06)\end{array}$ & $\begin{array}{c}2.035 \mathrm{E}-05 \\
(2.567 \mathrm{E}-06)\end{array}$ & & \\
\hline $\ln (P)$ & & & & & $\begin{array}{c}-0.335 \\
(0.024)\end{array}$ & $\begin{array}{l}-0.041 \\
(0.009)\end{array}$ \\
\hline $\ln (Y)$ & & & & & $\begin{array}{l}0.467 \\
(0.096)\end{array}$ & $\begin{array}{l}0.530 \\
(0.058)\end{array}$ \\
\hline$\varepsilon_{j}{ }^{\prime} S$ & $\mathrm{y}$ & y & $\mathrm{y}$ & $\mathrm{y}$ & $\mathrm{y}$ & $\mathrm{y}$ \\
\hline $\bar{R}^{2}$ & 0.85 & 0.94 & 0.85 & 0.94 & 0.85 & 0.94 \\
\hline$\hat{\sigma}$ & 1.081 & 0.407 & 0.027 & 0.011 & 0.027 & 0.011 \\
\hline
\end{tabular}


Table 3

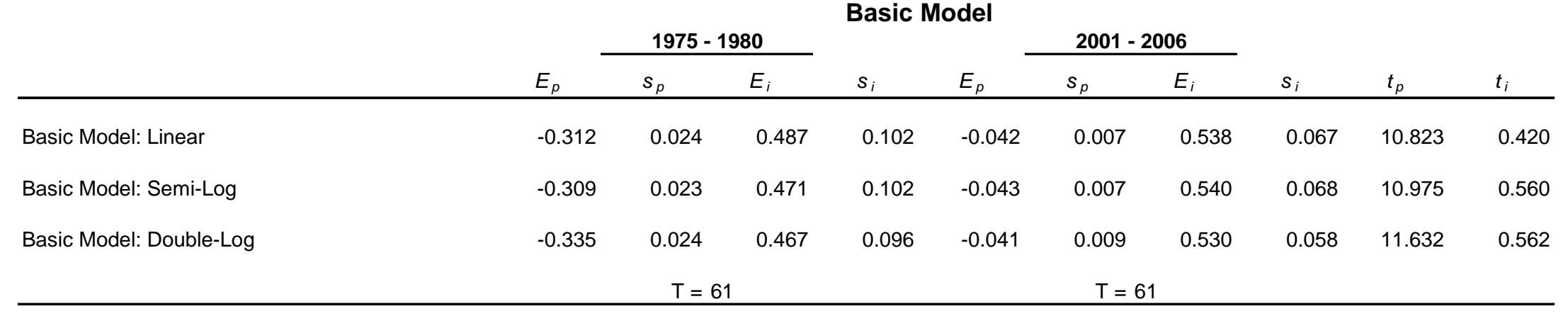


Table 4

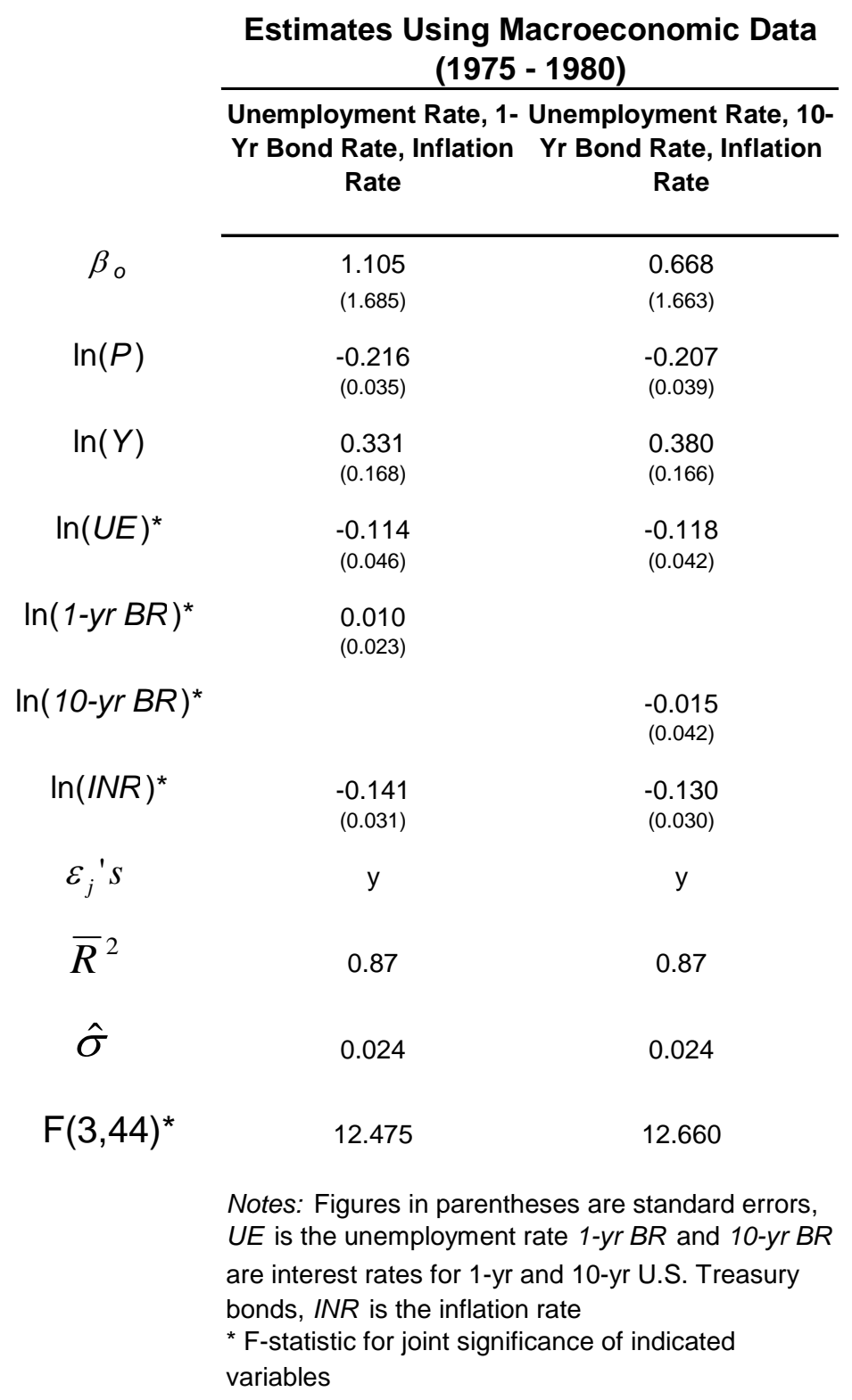


Table 5

Stage 1: Instrumental Variable Models (2001 2006)

\begin{tabular}{|c|c|c|c|}
\hline & & & \\
\hline & Crude Oil Quality & Production & ruptions \\
\hline & & (Venez., Iraq, USA) & (USA only) \\
\hline$\beta_{0}$ & -68.221 & -54.601 & -52.019 \\
\hline & $(15.067)$ & $(6.870)$ & $(6.757)$ \\
\hline $\ln (Y)$ & $\begin{array}{l}6.337 \\
(0.844)\end{array}$ & $\begin{array}{l}5.388 \\
(0.674)\end{array}$ & $\begin{array}{l}5.137 \\
(0.663)\end{array}$ \\
\hline $\ln (S)$ & $\begin{array}{r}-0.616 \\
(0.909)\end{array}$ & & \\
\hline $\ln (A P I)$ & $\begin{array}{l}1.238 \\
(2.493)\end{array}$ & & \\
\hline$V Z$ & & $\begin{array}{r}-0.077 \\
(0.050)\end{array}$ & \\
\hline IQ & & $\begin{array}{l}0.069 \\
(0.055)\end{array}$ & \\
\hline USA & & $\begin{array}{r}-0.346 \\
(0.092)\end{array}$ & $\begin{array}{c}-0.353 \\
(0.093)\end{array}$ \\
\hline$\varepsilon_{j}{ }^{\prime} S$ & $y$ & $\mathrm{y}$ & $\mathrm{y}$ \\
\hline $\bar{R}^{2}$ & 0.53 & 0.65 & 0.64 \\
\hline$\hat{\sigma}$ & 0.131 & 0.112 & 0.114 \\
\hline
\end{tabular}

Notes: Figures in parentheses are standard errors, $S$ is crude oil sulfur content, $A P I$ is crude oil specific gravity, RFM is refiner's margin, Venez, Iraq and USA are monthly crude oil production disruptions in Venezuela, Iraq and the United States in million barrels per day 
Table 6

Stage 2: Instrumental Variable Models (2001 - 2006)

\begin{tabular}{|c|c|c|c|}
\hline & $\begin{array}{c}\text { Crude Oil } \\
\text { Ouality }\end{array}$ & Production D & ruptions \\
\hline & & (Venez., Iraq, USA & (USA only) \\
\hline$\beta_{0}$ & 3.762 & -2.837 & -3.910 \\
\hline & (10.148) & $(1.185)$ & $(1.165)$ \\
\hline $\ln (P)$ & 0.048 & -0.060 & -0.077 \\
\hline & $(0.168)$ & $(0.016)$ & $(0.013)$ \\
\hline $\ln (Y)$ & -0.009 & 0.642 & 0.748 \\
\hline & $(1.002)$ & $(0.117)$ & $(0.115)$ \\
\hline$\varepsilon_{j}{ }^{\prime} S$ & $\mathrm{y}$ & $y$ & $\mathrm{y}$ \\
\hline $\bar{R}^{2}$ & 0.87 & 0.94 & 0.93 \\
\hline$\hat{\sigma}$ & 0.016 & 0.011 & 0.012 \\
\hline & $\begin{array}{l}\text { Notes: Figures } \\
\text { is the real price } \\
\text { is real per capit } \\
\text { dollars }\end{array}$ & $\begin{array}{l}\text { n parentheses are sta } \\
\text { of gasoline in constan } \\
\text { disposable income in }\end{array}$ & $\begin{array}{l}\text { dard errors, } P \\
2000 \text { dollars, } Y \\
\text { onstant } 2000\end{array}$ \\
\hline
\end{tabular}


Table 7

Price Income Interaction Model and Partial Adjustment Models

\begin{tabular}{|c|c|c|c|c|c|c|c|c|c|c|}
\hline & \\
\hline & \multicolumn{2}{|c|}{$\begin{array}{c}\text { Price-Income Interaction } \\
\text { Model }\end{array}$} & \multicolumn{2}{|c|}{$\begin{array}{l}\text { Partial Adjustment } \\
\text { Model: 1-month Lag }\end{array}$} & \multicolumn{2}{|c|}{$\begin{array}{l}\text { Partial Adjustment } \\
\text { Model: 12-month Lag }\end{array}$} & \multicolumn{2}{|c|}{$\begin{array}{l}\text { Partial Adjustment } \\
\text { Model: 1-month Lag wl } \\
\text { Month Dummies }\end{array}$} & \multicolumn{2}{|c|}{$\begin{array}{l}\text { Partial Adjustment } \\
\text { Model: 12-month Lag w/ } \\
\text { Month Dummies }\end{array}$} \\
\hline & $1975-1980$ & $2001-2006$ & $1975-1980$ & $2001-2006$ & $1975-1980$ & $2001-2006$ & $1975-1980$ & $2001-2006$ & $1975-1980$ & $2001-2006$ \\
\hline$\beta_{0}$ & $\begin{array}{c}-12.755 \\
(6.094)\end{array}$ & $\begin{array}{l}-6.286 \\
(1.491)\end{array}$ & $\begin{array}{l}-0.433 \\
(1.807)\end{array}$ & $\begin{array}{l}2.531 \\
(2.661)\end{array}$ & $\begin{array}{l}2.558 \\
(1.231)\end{array}$ & $\begin{array}{l}-0.724 \\
(0.878)\end{array}$ & $\begin{array}{l}-0.467 \\
(0.838)\end{array}$ & $\begin{array}{r}-1.482 \\
(0.361)\end{array}$ & $\begin{array}{l}0.533 \\
(1.102)\end{array}$ & $\begin{array}{l}-1.676 \\
(0.582)\end{array}$ \\
\hline $\ln (P), \Delta \ln (P)$ & $\begin{array}{l}27.572 \\
(13.678)\end{array}$ & $\begin{array}{c}10.297 \\
(3.223)\end{array}$ & $\begin{array}{l}-0.223 \\
(0.033)\end{array}$ & $\begin{array}{l}0.011 \\
(0.037)\end{array}$ & $\begin{array}{l}-0.240 \\
(0.031)\end{array}$ & $\begin{array}{l}-0.043 \\
(0.010)\end{array}$ & $\begin{array}{l}-0.300 \\
(0.039)\end{array}$ & $\begin{array}{l}-0.033 \\
(0.005)\end{array}$ & $\begin{array}{l}-0.303 \\
(0.028)\end{array}$ & $\begin{array}{l}-0.037 \\
(0.011)\end{array}$ \\
\hline $\ln (Y), \Delta \ln (Y)$ & $\begin{array}{l}1.720 \\
(0.630)\end{array}$ & $\begin{array}{l}0.981 \\
(0.146)\end{array}$ & $\begin{array}{l}0.325 \\
(0.192)\end{array}$ & $\begin{array}{l}0.071 \\
(0.256)\end{array}$ & $\begin{array}{l}-0.170 \\
(0.118)\end{array}$ & $\begin{array}{l}0.099 \\
(0.103)\end{array}$ & $\begin{array}{l}0.409 \\
(0.101)\end{array}$ & $\begin{array}{l}0.390 \\
(0.033)\end{array}$ & $\begin{array}{l}0.240 \\
(0.147)\end{array}$ & $\begin{array}{l}0.630 \\
(0.099)\end{array}$ \\
\hline $\ln (P) \ln (Y)$ & $\begin{array}{l}-2.879 \\
(1.413)\end{array}$ & $\begin{array}{l}-1.014 \\
(0.316)\end{array}$ & & & & & & & & \\
\hline $\ln G_{t-1}, \ln G_{t-12,} \varepsilon_{\tau-12}$ & & & $\begin{array}{l}0.299 \\
(0.060)\end{array}$ & $\begin{array}{l}0.112 \\
(0.049)\end{array}$ & $\begin{array}{l}0.783 \\
(0.081)\end{array}$ & $\begin{array}{l}0.929 \\
(0.081)\end{array}$ & $\begin{array}{l}0.107 \\
(0.106)\end{array}$ & $\begin{array}{l}0.330 \\
(0.074)\end{array}$ & $\begin{array}{l}0.275 \\
(0.117)\end{array}$ & $\begin{array}{l}-0.284 \\
(0.132)\end{array}$ \\
\hline$\varepsilon_{j}{ }^{\prime} s$ & $y$ & $y$ & $\mathrm{n}$ & $n$ & $\mathrm{n}$ & $\mathrm{n}$ & $y$ & $y$ & $y$ & $y$ \\
\hline $\bar{R}^{2}$ & 0.86 & 0.95 & 0.43 & -0.03 & 0.83 & 0.85 & 0.85 & 0.95 & 0.86 & 0.94 \\
\hline$\hat{\sigma}$ & 0.026 & 0.010 & 0.052 & 0.045 & 0.029 & 0.017 & 0.027 & 0.010 & 0.026 & 0.010 \\
\hline
\end{tabular}

Notes: Figures in parentheses are standard errors, $P$ is the real price of gasoline in constant 2000 dollars, $Y$ is real per capita disposable income in constant 2000 dollars $\ln G_{t-1}$ and $\ln G_{t-12}$ refer to 1 and 12 month lags of the dependent variable, per capital gasoline consumption 
Table 8

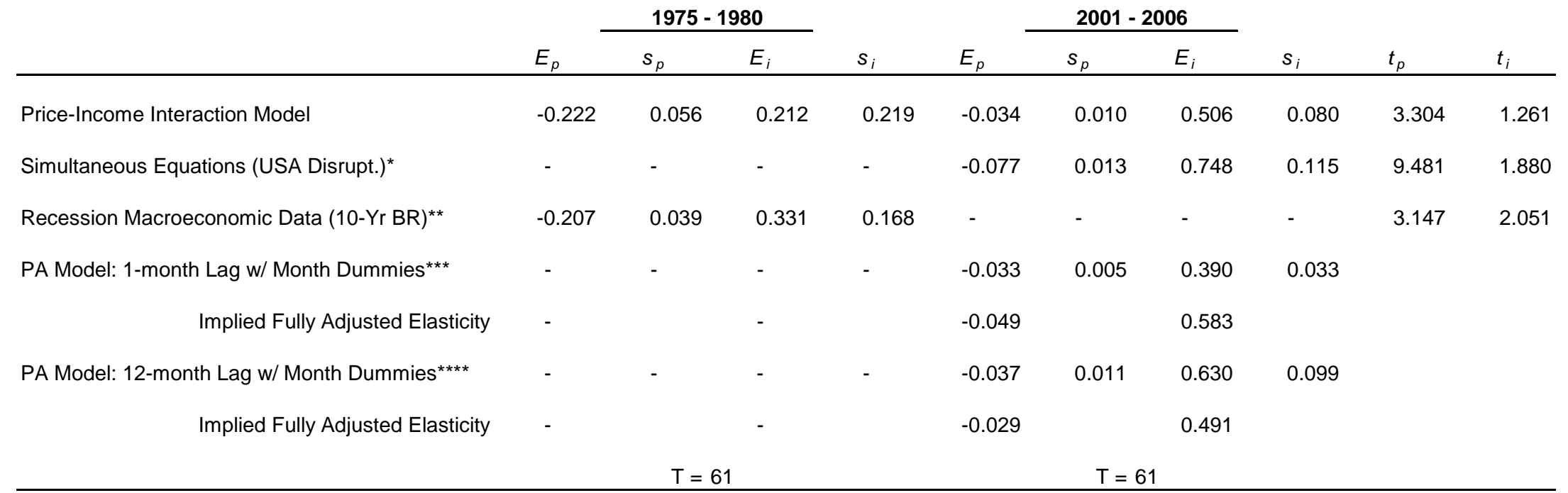

Notes: * No data available for simultaneous equations model for period from 1975 to 1980, t statistics are for 1975 to 1980 double-log model

** $\mathrm{t}$ statistics are for 2001 to 2006 simultaneous equations model

*** PA model, 1-month lag, 1975-1980 excluded because the coefficient on the lagged dependent variable is not significant

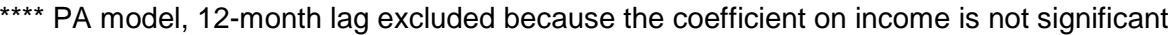


Figure 1

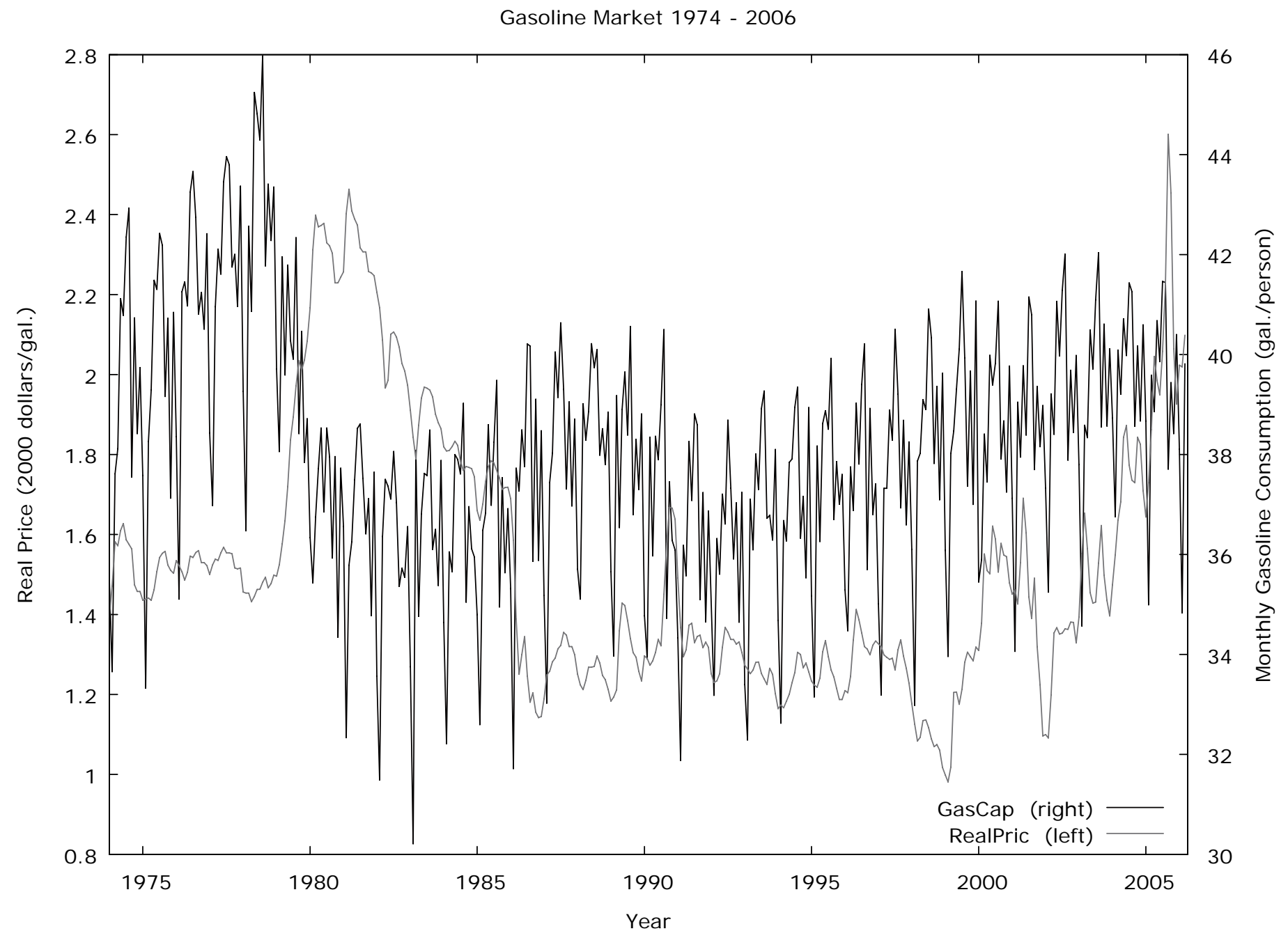


Figure 2

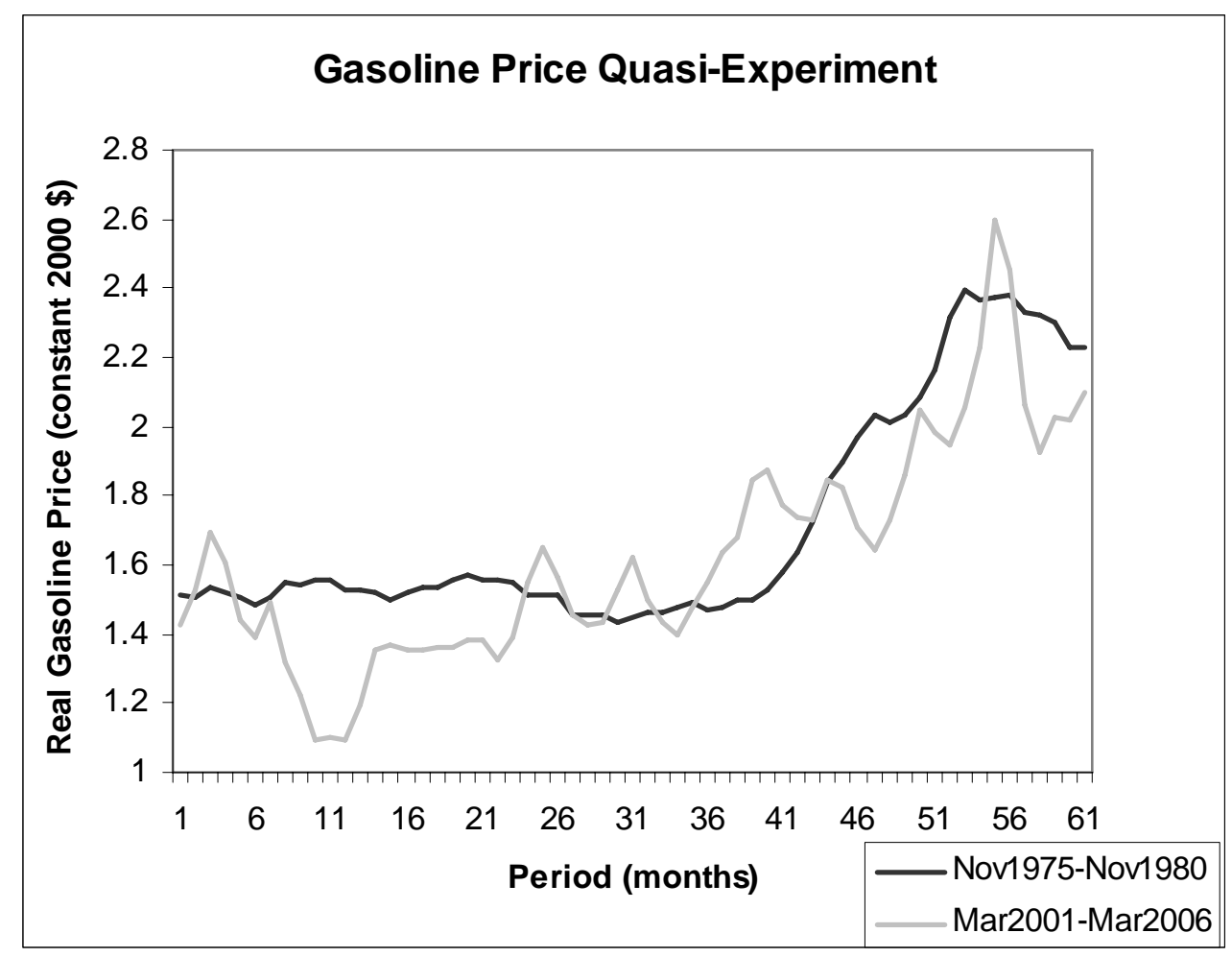




\section{Appendix - Alternative Specifications Data}

Additional data used in the alternative model specifications are defined as follows. Crude oil sulfur and API specific gravity are refiner crude oil input qualities reported by the U.S. Energy Information Administration (2006). The monthly crude oil production for Venezuela, Iraq and the United States are monthly average production in million barrels per day from the International Petroleum Monthly, U.S. Energy Information Administration (2006). Unemployment rates are U.S. aggregate for citizens over the age of 16 from the U.S. Bureau of Labor Statistics (2006). Interest rates are for one-year and ten-year U.S. Treasury Bills (constant maturities) as cited by the U.S. Federal Reserve Board (2006). Per capita quantities are calculated using mid-period monthly population from the Bureau of Economic Analysis (2006). 